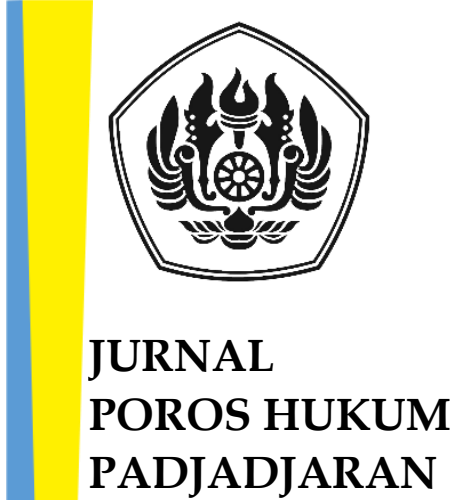

P-ISSN: 2715-7202

E-ISSN: $2715-9418$

Artikel diterbitkan:

29 Mei 2020

DOI:

https://doi.org/10.23920/jphp .v1i2.250

Halaman Publikasi:

http://jurnal.fh.unpad.ac.id/i ndex.php/JPHP/issue/archive

Diterbitkan oleh:

Fakultas Hukum

Universitas Padjadjaran

\section{KEDUDUKAN DAN TANGGUNG JAWAB NOTARIS SEBAGAI PIHAK DALAM PENYELESAIAN SENGKETA PERDATA DI INDONESIA TERKAIT AKTA YANG DIBUATNYA}

\section{POSITION AND RESPONSIBILITY OF NOTARY AS A PARTY TO THE RESOLUTION OF CIVIL DISPUTES IN INDONESIA RELATING TO THE DEED}

Anita Afriana ${ }^{a}$

\section{ABSTRAK}

Peran notaris sangat krusial dewasa ini digunakan oleh para pihak yang ingin membuat beragam perjanjian, dengan alasan akta notaris yang bersifat otentik dianggap masyarakat lebih terjamin kekuataan hukumnya daripada akta dibawah tangan. Namun dalam praktik, acapkali ditemukan adanya suatu akta notaris digugat untuk dimintakan pembatalan di muka pengadilan yang disebabkan karena kesalahan dari para pihak yang tidak sepakat dan tidak jujur dalam memberikan keterangannya terhadap notaris, atau kesalahan dari notaris itu sendiri baik karena kelalaiannya maupun karena kesengajaan. Penulisan artikel ini bersifat deskriptif analitis, dengan tujuan untuk melihat kedudukan notaris di pengadilan terkait penyelesaian sengketa baik dalam kapasitasnya sebagai pejabat negara maupun dari kedudukan akta otentik yang dihasilkannya serta tanggung jawab dari notaris/PPAT yang dianggap telah melakukan kesalahan ketika memberikan jasanya yang lebih lanjut dianggap merugikan pihak ketiga. Hasil menunjukkan bahwa dalam hal timbul permasalahan dikemudian hari atas terbitnya akta otentik yang dibuat oleh notaris, tidak serta merta notaris dapat ditarik sebagai pihak yang bersalah yang mengakibatkan persengketaan tetapi harus dilihat sejauhmana pelanggaran yang telah dilakukan oleh notaris, apakah ada kesalahan/tidak, pelanggaran terhadap kode etik dan atau UUJN. Dalam penyelesaian sengketa di pengadilan dalam sengketa perdata, notaris dapat saja berkedudukan sebagai pihak antara lain Tergugat jika dirasa telah melakukan perbuatan melawan hukum sehingga merugikan pihak lain, sebagai Turut Tergugat, atau saksi. Tanggung jawab notaris/PPAT tergantung dari kedudukannya dalam penyelesaian sengketa, namun pada intinya mempertanggungjawabkan perbuatannya baik secara perdata, pidana, maupun administratif.

Kata kunci: notaris; perdata; sengketa; tanggung jawab.

\footnotetext{
a Fakultas Hukum Universitas Padjadjaran, Jalan Raya Bandung-Sumedang KM.21 Jatinangor Kab. Sumedang, email:
} anita.afriana@unpad.ac.id 


\begin{abstract}
The role of a notary today is crucial for the parties who wish to make variety of agreements, due to authentic notarial deed is considered to be more secure for the society than the legal power of the deed under the hand. Nevertheless, in practice it is frequently discovered the presence of a notarial deed being sued to be requested for cancellation before the court due to the fault of the parties who disagree and dihonest in his statement to the notary, or the fault of the notary him/herself, either for negligence or willful misconduct. This article/is an analytical descriptive study, in order to see the position of the notary in the process of examination of dispute in court either as a person in his/her capacity as a state official or from the positions of the authentic deed made are often the source of disputes and and responsibility of the notary who is deemed to have made mistakes during undertaking further work that is considered detrimental to the third party. In terms of any problems that might arise in the future on the publication of an authentic deed made by the notary, the notary may not necessarily be drawn as the guilty party which caused the disputes, yet to be seen how far the offense has been committed by a notary, whether there is an error/not, a violation of the code of ethics and or the Law Number 2 of 2014 on the Position of Notary (hereinafter referred to as UUJN). In the dispute resolution in court on civil disputes, notaries can hold the position as the other party such as Defendant, if deemed to have committed an unlawful act to the detriment of others, as a codefendant, or witness. The responsibility of a notary/PPAT depends on his/her position in dispute resolution, but in essence, they are responsible for their actions, whether civil, criminal or administrative.
\end{abstract}

Keywords: notary; dispute; private; responsibility

\title{
PENDAHULUAN
}

Manusia sebagai subjek hukum yang memiliki hak dan kewajiban hukum baik terhadap dirinya sendiri maupun bagi orang lain yang didasarkan kepada nilai-nilai baik bagi dirinya sendiri maupun bagi orang lain yang didasarkan pada nilai-nilai kebiasaan dan norma yang tumbuh bersamaan dengan perkembangan masyarakat. Setiap individu yang sudah tergabung dalam kehidupan bermasyarakat tentu tidak akan terlepas dari apa yang dinamakan tanggung jawab. Siapa dan dimana saja keberadaannya baik yang akan, sedang maupun yang telah dilakukan tidak lepas dari suatu tanggung jawab. Pada dasarnya segala sesuatu yang dikerjakan oleh seseorang, baik dengan sengaja maupun tidak, harus dapat dimintakan pertanggungjawaban, yang tentunya selain tanggung jawab yang seseorang pegang, individu tersebut juga memiliki kewenangan, terlebih lagi yang berkaitan dengan etika profesi dari seorang profesi hukum.

Dengan adanya suatu hal yang menyangkut perlindungan nasib seseorang, maka tanggung jawab yang berat diletakkan di atas bahu anggota profesi hukum yang bersangkutan. Hal ini tidak hanya menyangkut kepentingan pribadi tetapi juga kepentingan umum. Tanggung jawab yang harus dibebankan kepada seorang profesi hukum dalam menjalankan tugas dan jabatan profesinya tidaklah ringan. Oleh karena itu, terhadap tanggung jawab profesi hukum diperlukan suatu ruang lingkup yang jelas, 
agar segala perbuatan yang dilakukan karena jabatannya dapat dipertanggungjawabkan.

Kedudukan notaris yang merupakan suatu profesi sebagai pejabat umum pembuat akta otentik tidak terlepas dari permasalahan yang berujung pada terjadinya konflik. Konflik akan berkembang menjadi sengketa apabila pihak yang merasa dirugikan menyatakan rasa tidak puas pada pihak yang menimbulkan kerugian pada pihak lain¹. Konflik maupun sengketa dapat dihindari apabila dalam suatu perbuatan hukum didasarkan pada kelengkapan surat atau dokumen yang memiliki kekuataan hukum sebagai bukti. Bukti dapat dibuat dengan kesepakatan para pihak yang dibuat dengan dilengkapi tanda tangan tanpa legalitas pejabat yang berwenang (akta dibawah tangan) maupun berupa akta otentik.

Akta otentik merupakan alat bukti yang terkuat, terpenuh serta mempunyai peranan yang penting pada setiap hubungan hukum dalam kehidupan masyarakat sebagai kebutuhan pembuktian tertulis terhadap peristiwa hukum, baik dalam bidang ekonomi maupun sosial ${ }^{2}$. Alat bukti otentik memiliki peranan yang sangat penting dalam setiap hubungan hukum dalam kehidupan bermasyarakat yaitu sebagai alat bukti paling akurat dan tinggi nilainya dalam pembuktian, dalam hubungan bisnis, kegiatan di bidang perbankan, pertanahan, kegiatan sosial dan lain sebagainya. ${ }^{3}$

Lembaga yang dibuat dan diciptakan oleh negara dalam penataan hukum diantaranya adalah Lembaga Kenotariatan dengan menempatkan notaris sebagai pejabat umum yang dilandasi keahlian untuk membuat akta otentik dan kewenangan lainnya yang diberikan oleh pemerintah sepanjang pembuataan akta-akta tersebut tidak ditugaskan atau dikecualikan kepada pejabat lain.

Perbuatan hukum yang dilakukan seseorang dengan bukti tertulis yang kemudian hal tersebut dituangkan dalam akta otentik merupakan bukti otentik yang memuat kebenaran formil tentang adanya suatu perbuatan hukum tertentu yang dilakukan oleh seseorang. Perbuatan hukum tersebut menentukan secara jelas hak dan kewajiban terhadap orang yang melakukannya, menjamin kepastian hukum dan pembuktian atas perbuatan hukum tersebut. Kemudian dengan semakin meningkatnya perkembangan

\footnotetext{
1 Dewi Tuti Muryati dan B. Dini Heryanti, (2011). “Pengaturan dan Mekanisme Penyelesaian Sengketa Non Litigasi di Bidang Perdagangan", Jurnal Dinamika Sosbud, Vol.13, No. 1, Juni hlm. 49.

2 A Kohar, (1983). Notaris Dalam Praktik Hukum, Bandung: Alumni, hlm 64-66.

3 Suyitno LS, (2007). Pejabat Pembuat Akta Tanah, (Makalah disampaikan pada Kongres IV Ikatan Pejabat Pembuat Akta Tanah (IPPAT) dan Up Grading Refreshing Course, Surabaya, 30-31 Agustus-1 September 2007), hlm. 1.
} 
hukum dan kebutuhan masyarakat yang menuntut akan kepastian hukum suatu hal, terkhusus dalam hal pembuktian tertulis berupa akta otentik pada era globalisasi ini, maka diharapkan hal tersebut menjadi suatu perhatian khusus, sehingga diharapkan dapat menghindari terjadinya suatu sengketa yang terjadi diantara para pihak, sehingga menimbulkan tidak adanya suatu kepastian hukum di dalam masyarakat. Sengketa yang terjadi timbul karena adanya ketidaksesuaian kepentingan para pihak, sehingga dengan adanya akta otentik diharapkan dapat menyelesaikan permasalahan seperti itu.

Pasal 1 angka 1 Undang-Undang Nomor 2 Tahun 2014 Tentang Perubahan Atas Undang-Undang No. 30 Tahun 2004 Tentang Jabatan Notaris (UUJN) menyebutkan "Notaris adalah pejabat umum yang berwenang untuk membuat akta otentik dan kewenangan lainnya sebagaimana dimaksud dalam UUJN." Notaris diangkat dan diberhentikan oleh Menteri yang tugas dan tanggung jawabnya meliputi bidang kenotariatan yaitu Menteri Hukum dan Hak Asasi Manusia, namun Notaris tidak menjadi subordinasi dari pemerintah dan bersifat mandiri. Notaris tidak dapat diintervensi oleh pemerintah dalam menjalankan tugas jabatan.

Notaris sebagai pejabat publik berbeda dengan Pejabat Tata Usaha Negara. Perbedaannya terletak pada produk yang dihasilkan. Produk akhir notaris sebagai pejabat publik adalah akta otentik yang terikat dalam ketentuan hukum perdata, terutama dalam pembuktian.

Akta merupakan formulasi keinginan atau kehendak para pihak yang dituangkan dalam akta Notaris yang dibuat dihadapan atau oleh Notaris. Sengketa dalam bidang perdata diperiksa di Peradilan Umum, sedangkan sengketa dalam Hukum Administrasi Negara diperiksa di Peradilan Tata Usaha Negara.

Notaris merupakan wakil pemerintah yang membantu dan melayani masyarakat yang memerlukan jasa dalam pembuatan akta otentik sebatas masih menjadi kewenangannya. Kewenangan Notaris ditentukan dalam Pasal 15 UUJN. Pasal 15 ayat (1) UUJN menyebutkan salah satu kewenangan Notaris, yaitu:

“Notaris berwenang untuk membuat akta otentik mengenai perbuatan, perjanjian, dan ketetapan yang diharuskan oleh peraturan perundangundangan atau yang dikehendaki oleh para pihak untuk dinyatakan dalam akta otentik, menjamin kepastian tanggal pembuatan akta, menyimpan akta, memberikan grosse, salinan dan kutipan akta". 
Pembuatan akta otentik diserahkan kepada Notaris sepanjang tidak ditugaskan atau dikecualikan kepada orang lain oleh undang-undang. Notaris dapat mempunyai kewenangan lain yang diatur dalam peraturan perundang-undangan yang berbeda, misalnya saja kewenangan notaris ditentukan dalam Undang-Undang No. 40 Tahun 2007 Tentang Perseroan Terbatas ( UUPT), yaitu dalam proses Rapat Umum Perseroan Terbatas ( RUPS), dihadiri pula oleh notaris guna mencatat segala aktifitas RUPS agar memenuhi ketentuan undang-undang sehingga segala yang diputuskan dalam RUPS tersebut mengikat bagi PT. Hasil rapat dalam RUPS tersebut selanjutnya akan dibuatkan risalah rapat atau risalah RUPS atau akta berita acara rapat. Notaris juga berwenang membuat risalah lelang, membuat perjanjian perkawinan yang para pihaknya tunduk pada ketentuan BW maupun UU No. 1 Tahun 1974 Tentang Perkawinan, dan kewenangan membuat perjanjian lainnya. Pejabat Pembuat Akta Tanah yang sudah tentu sebagai notaris memiliki kewenangan untuk membuat akta tanah.

Uraian di atas menunjukkan bahwa peran notaris sangat krusial dewasa ini digunakan oleh para pihak yang ingin membuat beragam perjanjian, dengan alasan akta notaris yang bersifat otentik dianggap masyarakat lebih terjamin kekuataan hukumnya daripada akta dibawah tangan. Hal ini sangat beralasan mengingat Akta Notaris termasuk kedalam akta otentik yang mempunyai kekuatan pembuktian yang sempurna. Philipus M. Hadjon mengatakan “syarat akta otentik adalah di dalam bentuk yang ditentukan oleh undang-undang, dan dibuat oleh dan dihadapan Pejabat Umum".

Pembuatan akta notaris harus berdasarkan perintah peraturan perundangundangan dan keinginan para pihak. Notaris yang membuat akta tidak berkedudukan sebagai pihak bersama-sama para penghadap yang namanya tercantum dalam akta. Akta yang dibuat oleh Notaris disebut Akta Relaas, yang berisi uraian Notaris mengenai hal yang dilihat dan disaksikan Notaris sendiri atas permintaan para pihak, agar tindakan para pihak dituangkan ke dalam bentuk akta notaris.

Pada hakikatnya, akta otentik memuat kebenaran formal sesuai dengan apa yang diberitahukan para pihak kepada notaris, dan notaris menuangkannya bahwa apa yang termuat dalam akta otentik telah dimengerti dan sesuai dengan kehendak dari para pihak, kemudian membacakannya sehingga jelas isi dari akta notaris tersebut yang disertai dengan memberikan akses informasi dan peraturan perundang-undangan yang terkait terhadap para pihak yang membuatnya. Oleh sebab itu, para pihak dapat 
menentukan dengan bebas untuk menyetujui atau tidak mengenai isi akta yang akan ditandatanganinya. ${ }^{4}$

Seorang notaris dalam menjalankan tugasnya sebagai pejabat umum merupakan lembaga yang tidak boleh terlepas dari rambu-rambu yang harus ditaatinya. Salah satunya adalah peraturan tentang persyaratan untuk dapat diangkat sebagai notaris, yaitu meliputi pengetahuan hukum dan ilmu-ilmu lainnya, khususnya keahlian dibidang ilmu kenotariatan yang harus dikuasai secara integrasi oleh notaris, sehingga lancar dalam merancang, menyusun, dan membuat berbagai akta otentik. Dengan demikian susunan bahasa, teknik yuridisnya rapi, baik, dan benar.

Syarat-syarat yang telah ditentukan dalam UUJN dan peraturan perundangundangan lain yang umum mengatur tentang kewajiban notaris yang harus dipenuhi, agar akta yang dibuatnya mempunyai otensitas, karena fungsi notaris bukan hanya sekedar mencatat dan membuat alat bukti mengenai perbuatan hukum pihak-pihak yang dicantumkan dalam akta saja, melainkan juga untuk mengupayakan agar urusan yang dipercayakan kepadanya dapat berjalan sesuai dengan hukum yang berlaku. ${ }^{5}$

Dalam praktik, masih ditemukannya adanya suatu akta notaris digugat untuk dimintakan pembatalan di muka pengadilan yang disebabkan karena kesalahan dari para pihak yang tidak sepakat dan tidak jujur dalam memberikan keterangannya terhadap notaris, atau kesalahan dari notaris itu sendiri baik karena kelalaiannya maupun karena kesengajaan. Salah satu contoh kasus yang terjadi adalah notaris membuat akta risalah RUPS dengan memalsukan tanda tangan, atau akta jual beli yang mana notaris tahu adanya data yang tidak jujur dari pihak penghadap. Terlepas dari kesengajaan atau keikutsertaan notaris atau adanya kelalaian notaris, pada prinsipnya notaris/PPAT menurut UUJN hatus bertindak secara saksama.

Akta notaris yang memiliki kekuataan hukum sempurna untuk membuktikan adanya perbuatan hukum, dalam praktik sering menjadi sumber konflik bahkan sengketa. Tidak jarang kita temukan misalnya ada 2 (dua) akta berlainan yang menerangkan satu perbuatan yang sama. Dalam konteks perdata yang berkaitan dengan hak dan kebendaan, keadaan tersebut seringkali berujung pada penyelesaian sengketa

\footnotetext{
${ }^{4}$ Habib Adjie, (2009). Hukum Notaris Indonesia (Tafsir Tematik Terhadap Undang-Undang Nomor 30 Tahun 2004 Tentang Jabatan Notaris), Bandung: PT. Refika Aditama, hlm. 16-19.

5 Komar Andasasminta, (1983). Notaris Selayang Pandang, Alumni: Bandung, hlm. 15.
} 
di pengadilan, karena keberadaan akta otentik tersebut dianggap merugikan hak salah satu pihak.

Berbicara mengenai penyelesaian sengketa di pengadilan, maka yang digunakan sebagai sumber Hukum Acara Perdata adalah ketentuan HIR yang berlaku untuk wilayah Jawa dan Madura dan RBg untuk wilayah luar Jawa dan Madura, dan berbagai ketentuan peraturan perundang-undangan lainnya.

Sebagai hukum formal yang digunakan untuk menyelesaikan sengketa di pengadilan, terdapat tahap-tahap yang digunakan dalam proses beracara dan bersifat memaksa, mulai dari mengajukan gugatan, proses jawab-menjawab, pembuktian, kesimpulan, hingga putusan. Pembuktian merupakan tahapan yang terpenting sebelum hakim memberikan putusan, karena masing-masing pihak wajib membuktikan dalildalil yang dikemukakannya dalam memori yang disampaikan ke persidangan, yaitu memberi keyakinan kepada hakim tentang kebenaran dalil atau dalil-dalil yang dikemukakan dalam suatu persidangan ${ }^{6}$. Salah satu tugas hakim ialah menyelidiki apakah yang menjadi dasar perkara benar-benar ada atau tidak. Hubungan inilah yang harus terbukti di muka hakim dan tugas kedua belah pihak yang berperkara ialah memberi bahan-bahan bukti yang diperlukan oleh hakim ${ }^{7}$.

Fungsi pembuktian adalah berusaha memberikan kepastian tentang kebenaran fakta hukum yang menjadi pokok sengketa bagi hakim ${ }^{8}$, karenanya hakim akan selalu berpedoman pada hasil pembuktian dalam menjatuhkan putusan. Oleh karena itu, acara pembuktian menempati posisi terpenting dalam jalannya persidangan di pengadilan, sebagaimana dinyatakan pula oleh Efa Laela Fakhriah bahwa tahapan pembuktian menjadi sangat penting karena kedua pihak mengajukan bukti-bukti yang mendukung pernyataan para pihak sebelumnya ${ }^{9}$. Namun demikian, A Pitlo berpendapat bahwa bukti di dalam hukum tidak pernah akan mencapai kebenaran yang mutlak, akan tetapi hanya akan mencapai kebenaran yang relatif. ${ }^{10}$

Berkaitan dengan pembuktian, akta otentik yang salah satunya merupakan produk notaris, dijadikan sebagai alat bukti tertulis dalam penyelesaian sengketa

\footnotetext{
Subekti, (1991). Hukum Pembuktian, Jakarta: Pradnya Paramita, hlm. 7.

7 Anita Afriana, et.all (2020). Hukum Perlindungan Konsumen: Dimensi Penyelesaian Sengketa, Bandung: Global Sinergi, hlm. 40.

8 Bahtiar Effendi dkk, (1991). Surat Gugatan dan Hukum Pembuktian Dalam Perkara Perdata, Bandung: Citra Aditya Bakti, hlm 50 .

9 Efa Laela Fakhriah, (2015). “Perkembangan Alat Bukti dalam Penyelesaian Perkara Perdata di Pengadilan menuju Pembaharuan Hukum Acara Perdata", Jurnal Hukum Acara Perdata, Vol 1 No. 2

10 Bambang Waluyo, (1992). Sistem Pembuktian dalam Peradilan Indonesia, Jakarta: Sinar Grafika, hlm. 3.
} 
perdata, demikian pula kedudukan dari notaris yang membuat akta tersebut seringkali pula dijadikan sebagai pihak (tergugat atau turut tergugat) atau saksi dalam pemeriksaan perkara perdata oleh hakim di pengadilan.

Artikel ini lebih lanjut akan meninjau kedudukan notaris dalam pemeriksaan sengketa di pengadilan baik sebagai pribadi dalam kapasitasnya sebagai pejabat negara maupun dari kedudukan akta otentik yang dihasilkannya acapkali menjadi sumber persengketaan. Secara teori akta otentik dapat saja tergradasi menjadi akta di bawah tangan jika syaratnya tidak terpenuhi sebagaimana diatur dalam UUJN. Demikian pula akan dilihat bagaimana tanggung jawab dari notaris yang dianggap dalam beberapa kasus telah melakukan kesalahan ketika melakukan pekerjaannya yang lebih lanjut dianggap merugikan pihak ketiga.

\section{METODE PENELITIAN}

Penulisan artikel ini bersifat deskriptif analitis dengan cara menjabarkan kedudukan notaris sebagai pihak dalam penyelesaian sengketa perdata di pengadilan dengan menguraikan teori-teori yang relavan berikut peraturan perundang-undangan. Sebagai bagian dari penelitian hukum maka metode yang digunakan adalah yuridis normatif, yang mengedepankan data sekunder berupa teori, asas, dan kaidah hukum.

\section{PEMBAHASAN}

\section{Kedudukan Notaris dalam Penyelesaian Sengketa Perdata di Pengadilan}

Notaris adalah salah satu pejabat negara yang perannya sangat dibutuhkan di masa sekarang. Saat ini, masyarakat tidak lagi hanya mengenal perjanjian yang didasarkan atas kepercayaan satu sama lain. Setiap perjanjian yang dilakukan oleh masyarakat pasti akan mengarah kepada notaris sebagai sarana keabsahan perjanjian yang mereka lakukan. Karena itulah, kedudukan notaris menjadi semakin penting dewasa ini.

Notaris juga memiliki kewenangan tersendiri yag tidak dimiliki oleh pejabat negara lainnya. Para notaris juga memiliki kewajiban dan larangan yang wajib mereka patuhi dalam pelaksanaan tugas jabatannya. Dengan berdasar pada UUJN, para notaris di Indonesia wajib untuk memahami apa yang menjadi kewenangan dan kewajibannya, serta larangan yang tidak boleh dilakukan dalam pelaksanaan tugas dan jabatannya. 
Notaris wajib mengetahui batasan yang dimilikinya, begitu pula kewajiban serta larangan yang tidak boleh dilakukan.

Substansi akta notaris merupakan formulasi atas keterangan pernyataan dari keinginan para penghadap yang dikemukakan dihadapan notaris. Notaris tidak dapat memaksakan keinginannya atau pendapatnya agar diikuti oleh para penghadap kemudian dituangkan ke dalam akta. Tugas notaris sebelum penandatangan suatu akta, terlebih dahulu harus mempertimbangkan diri pribadi para penghadap, khususnya yang berkaitan dengan kecakapan bertindak para penghadap, yang merupakan syarat umum untuk melakukan pebuatan hukum secara sah. Hal ini dikarenakan orang yang membuat perjanjian nantinya akan terikat oleh perjanjian yang dibuatnya, oleh karenanya segala tanggung jawab yang bakal dipikulnya akibat perbuatan yang dilakukannya. Dalam pembuatan akta, notaris juga harus mempertimbangkan keadaan pribadi para penghadap dalam pengertian yuridis sebagaimana yang diatur dalam Pasal 39 ayat (2) UUJN yang menegaskan bahwa penghadap harus dikenal oleh notaris atau diperkenalkannya kepadanya oleh 2 (dua) orang saksi pengenal.

Dalam menjalankan tugasnya, notaris berkewajiban untuk menjelaskan bahwa apa yang termuat dalam akta notaris sungguh-sungguh telah dipahami dan dimengerti dan sesuai dengan kehendak para pihak, yaitu dengan cara membacakannya sehingga isi dari akta itu jelas bagi para pihak. Tindakan ini wajib dilakukan oleh notaris dalam menjalankan kewenangannya dalam membuat semua jenis akta. Oleh karenanya para pihak dapat menentukan dengan bebas untuk menyetujui atau tidak terhadap isi akta yang akan ditandatanganinya. Penandatangan akta menunjukkan bahwa akta tersebut mengikat atau tidaknya.

Berdasarkan Pasal 3 Kode Etik Notaris, dikatakan bahwa notaris memiliki kewajiban, yaitu salah satunya menjalankan jabatan notaris terutama dalam pembuatan, pembacaan, dan penandatanganan akta. Kode etik menjadi pedoman perilaku notaris apakah layak/tidak layak, patut atau tidak perbuatan dilakukan. Kode etik merupakan code of conduct yang tidak memberi sanksi secara hukum tetapi sanksi secara moral.

Notaris dituntut melakukan pembuatan akta dengan baik dan benar, artinya akta yang dibuatnya harus berdasarkan undang-undang yang berlaku dalam memenuhi permintaan pihak-pihak yang berkepentingan. Sehingga dengan hal ini, notaris dapat memberikan kepastian kepada kliennya bahwa akta yang dibuatnya tidak ada cacat yang dapat menimbulkan masalah dikemudian hari karena notaris telah menjalankan 
tugasnya sesuai dengan peraturan perundang-undangan yang berlaku. Dalam praktik banyak kasus yang terjadi yang disebabkan karena kelalaian maupun kesengajaan dari notaris misalnya notaris yang membuat akta tentang perubahan anggaran dasar perseroan terbatas yang telah daluarsa. Perubahan anggaran dasar harus memenuhi syarat yang ditentukan oleh undang-undang oleh karena kesalahan yang dilakukan notaris harus dapat dipertanggungjawabkan. Berdasarkan data yang didapat dari Pengawas Notaris Kota Bandung pun didapatkan data cukup banyak pelanggaran yang dilakukan notaris berkenaan dengan kode etik ${ }^{11}$. Seringkali ditemukan akta otentik yang di dalamnya memuat keterangan yang tidak benar, atau dengan kata lain memuat keterangan palsu. Salah satu contohnya yaitu terdapat pada Surat Keterangan Waris yang dituangkan dalam akta otentik yang di dalamnya memuat keterangan tidak benar pada Putusan Mahkamah Agung Nomor 121/Pid/2017/PT.DKI. Dalam kasus perkara Putusan Mahkamah Agung Nomor 121/Pid/2017/PT.DKI mengenai sumpah palsu dan keterangan palsu, terdakwa yang bernama Hamid Dharma diketahui membuat keterangan waris di Kantor Notaris Ny. Julia Rochana Murat, S.H terhadap ruko bersama yang terletak di Jl. Gunung Sahari I No. 42 A Sawah Besar Jakarta Pusat, Kios di Lt. V Blok A No. 76 Plaza Athrium Senen dan Kios di Lt. V Blok A No. 57-58 Plaza Athrium Senen Jakarta Pusat milik Alm. David Dharma dan saksi Irwan. Alm. David Dharma merupakan adik dari terdakwa dan Almh. Teh Tjhoen Eng. Alm David Dharma meninggal pada tanggal 23 Februari 2000 tanpa mempunyai isteri dan anak. Bahwa keterangan waris yang dibuat oleh terdakwa diketahui memuat keterangan palsu atau keterangan tidak benar, yakni dalam membuat keterangan waris tersebut terdakwa tidak memberi tahu dan tidak memasukkan nama saksi Lucky dan Tony selaku ahli waris. Padahal saksi Lucky dan Toni merupakan anak dari Almh. Teh Tjhoen Eng yang merupakan kakak dari Alm David Dharma. Terdakwa dalam membuat keterangan waris menyatakan bahwa ibu dari saksi Lucky dan Tony (Almh. Teh Tjhoen Eng) meninggal tanpa meninggalkan ahli waris karena tidak pernah menikah. Keterangan waris tersebut termuat dalam Akta Waris No. 17 tanggal 14 April tahun 2000 yang ditandatangani oleh Notaris Ny. Julia Rochana Murat, S.H dan tidak menyertakan nama

${ }^{11}$ Data didapat dari Majelis Pengawas Daerah Notaris ( MPDN) Kota Bandung tahun 2018-2019. 
saksi Lucky dan Tony selaku ahli waris. Dengan adanya keterangan waris tersebut jelas memberikan kerugian bagi saksi Lucky dan Tony ${ }^{12}$

Sebagai produk yang dihasilkan oleh notaris, akta notaris merupakan akta otentik yang dibuat oleh atau dihadapan notaris menurut bentuk dan tata cara yang ditetapkan oleh undang-undang. Akta otentik sebagai bukti terkuat dan terpenuh mempunyai peranan penting dalam setiap hubungan hukum dalam kehidupan masyarakat. Dengan demikian, melalui akta otentik dapat ditentukan secara jelas hak dan kewajiban, sehingga dapat menjamin kepastian hukum dan menghindari terjadinya sengketa. Dalam hal terjadinya sengketa, sesungguhnya akta otentik merupakan bukti terkuat dan terpenuh bagi penyelesaian sengketa perdata pada umumnya.

Akta otentik mempunyai peran penting dalam hubungan hukum masyarakat, karena para pihak dapat menggunakannya sebagai alat bukti dari peristiwa hukum yang telah dilakukan, baik dalam persidangan acara perdata maupun acara pidana. Alat-alat bukti dalam acara perdata ditentukan secara limitatif pada Pasal 164 HIR. Jenisjenis alat bukti dalam acara perdata yang terbatas membuat para pihak yang berperkara terikat dengan jenis-jenis alat bukti yang sudah ditentukan dan hakim hanya menilai berdasarkan alat-alat bukti yang diajukan para pihak, dan memutuskan sebatas tuntutan yang diajukan oleh para pihak.

Akta otentik termasuk dalam jenis alat bukti tertulis, namun tidak semua tulisan dapat menjadi alat bukti di persidangan. Sudikno Mertokusumo berpendapat bahwa "tulisan yang dapat dijadikan sebagai alat bukti adalah segala sesuatu yang memuat tanda baca yang dimaksudkan untuk mencurahkan isi hati atau untuk menyampaikan buah pikiran seseorang dan dipergunakan sebagai pembuktian. Akta adalah surat sebagai alat bukti yang diberi tanda tangan, yang memuat peristiwa yang menjadi dasar suatu hak atau perikatan, yang dibuat sejak semula dengan sengaja untuk pembuktian ${ }^{13}$. Akta otentik yang dibuat oleh Notaris merupakan akta yang mempunyai kekuatan hukum dan mempunyai kekuatan pembuktian yang sempurna bagi para pihak atau pihak lain yang mendapat hak dari para pihak. Apabila suatu pihak mengajukan suatu akta otentik sebagai alat bukti, Majelis Hakim harus menerimanya dan menganggap apa yang dituliskan di dalam akta itu benar terjadi, karena kedudukan akta sebagai alat

\footnotetext{
${ }^{12}$ Dapat dilihat dalam Shafira Meidina Rafaldini; Anita Afriana, Pupung Faisal, (2020). "Surat Keterangan Waris yang Memuat Keterangan tidak Benar Dikaitkan dengan Kekuatan Pembuktiannya sebagai Akta Otentik', Jurnal Hukum Acara Perdata, Vol 6 No. 1, hlm. 58.

${ }^{13}$ Sudikno Mertokusumo, (2009). Hukum Acara Perdata di Indonesia Edisi Ke Delapan, Yogyakarta: Liberty, hlm. 151.
} 
bukti yang pertama dan utama dalam penyelesaian perkara perdata, serta akta otentik dengan kekuataan pembuktian yang sempurna.

Notaris harus selalu bersikap hati-hati agar tidak melakukan kesalahan dalam pembuatan akta otentik, namun tidak tertutup kemungkinan masih terdapat kesalahan yang dilakukan Notaris. Para pihak yang dirugikan karena kesalahan notaris dalam pembuatan akta dapat meminta pertanggungjawaban notaris dengan mengajukan gugatan ke pengadilan.

Terkait kedudukan seorang notaris dalam penyelesaian sengketa perdata, dapat dilihat dari konteksnya apakah notaris tersebut memang melakukan kesalahan sehingga dapat dikualifikasikan melakukan perbuatan melawan hukum, berdasarkan Pasal 1365 KUHPerdata, sehingga dalam hal ini notaris haruslah dijadikan sebagai Tergugat karena telah melakukan kesalahan diluar kode etiknya dan hal tersebut merugikan orang lain. Diluar itu, notaris dapat pula berkedudukan sebagai Turut Tergugat atau saksi di persidangan.

Berbeda dengan saksi, dalam suasana Hukum Acara Perdata dikenal 2 (dua) macam saksi, yaitu saksi-saksi yang secara kebetulan melihat, mendengar sendiri peristiwa-peristiwa yang menjadi persoalan. Saksi ini untuk datang ke persidangan, saksi tersebut disumpah terlebih dahulu, dan memberikan kesaksian di bawah sumpah. Kedua adalah saksi-saksi yang pada waktu perbuatan hukum itu dilakukan, sengaja telah diminta untuk menyaksikan perbuatan hukum tersebut. Yang dapat diterangkan oleh saksi hanyalah apa yang dilihat, didengar atau rasakan sendiri. Seorang saksi dilarang untuk menarik suatu kesimpulan, karena hal itu adalah tugas hakim. Saksi yang akan diperiksa sebelumnya harus bersumpah menurut cara agamanya atau berjanji, bahwa akan menerangkan yang sebenarnya. Setelah disumpah saksi wajib memberikan keterangan yang benar. Namun sesungguhnya, pihak yang mempermasalahkan kebenaran materiil dari akta notaris tidak dapat menggugat karena akta notaris hanya memuat kebenaran formil.

\section{Tanggung Jawab Notaris dalam Persengketaan Perdata}

Terkait dengan kewenangan seseorang dalam menjalankan jabatannya, maka kewenangan tersebut selalu diikuti dengan pertanggungjawaban setelah menjalankan kewenangan. Berdasarkan Ilmu Hukum Perdata, dasar pertanggungjawaban dibagi menjadi dua macam, yaitu kesalahan dan risiko. Dengan demikian, dikenal dengan 
pertanggungjawaban atas dasar kesalahan (liability based on fault) dan pertanggungjawaban tanpa kesalahan yang dikenal (liability without fault) yang dikenal dengan tanggung jawab risiko. Prinsip dasar pertanggungjawaban atas dasar kesalahan mengandung arti bahwa seseorang harus bertanggung jawab karena melakukan kesalahan yang merugikan orang lain, sedangkan prinsip dasar tanggung jawab risiko adalah kewajiban yang timbul akibat risiko dari jabatan atau kedudukan, walaupun risiko tersebut timbul karena suatu perbuatan dilakukan oleh orang lain yang di bawah pegawasannya.

Dikaji dari sejarahnya, teori tanggungjawab hukum telah berkembang dari tanggung jawab yang berdasarkan kesalahan (fault) yang mencakup kelalaian (neligence) dan ketidakpatutan (misappropriation/misrepresentation) dan tanggung Jawab berdasarkan wanprestasi (breach of contract), kemudian menjadi tanggung jawab tanpa kesalahan. Kemudian, dengan berkembangnya zaman yang makin menghasilkan resiko yang bertambah besar dan makin rumitnya hubungan sebab akibat dalam penentuan risiko, maka teori hukum telah meninggalkan konsep tanggung jawab kesalahan menjadi konsep tanggung jawab atas risiko. Prinsip kepatuhan hukum dalam suatu tata kelola yang baik, maka secara hukum perlu dilihat dulu bagaimana perkembangan teori dan konsep tanggung jawab hukum serta perbuatan melawan hukum. Konsep tanggung jawab hukum (liability) akan merujuk pada tanggung jawab pada hukum publik (mencakup tanggung jawab hukum administrasi negara dan tanggung jawab hukum pidana), dan tanggung jawab dalam hukum privat (perdata). ${ }^{14}$

Notaris dapat berbuat salah mengenai isi akta karena informasi yang salah dari para pihak, namun kesalahan tersebut tidak dapat dipertanggungjawabkan kepada notaris karena isi akta telah dikonfirmasikan kepada para pihak. Minuta akta wajib dibuat notaris dan didalamnya terdapat tanda tangan penghadap yang merupakan persetujuan dari penghadap terhadap isi akta notaris.

Pasal 84 UUJN menyebutkan mengenai bentuk-bentuk pelanggaran yang apabila dilakukan notaris dapat mengakibatkan akta notaris menjadi batal demi hukum atau hanya mempunyai kekuataan sebagai akta dibawah tangan. Akta yang dinyatakan batal demi hukum oleh Majelis Hakim Pengadilan Negeri karena notaris melanggar ketentuan yang terdapat dalam UUJN dapat menyebabkan notaris dijatuhi sanksi

\footnotetext{
${ }^{14}$ Anang Ade Irawan, dkk, (2018). "Pertanggungjawaban Ahli Waris Notaris sebagai Pejabat Umum atas Akta Notaris yang Menimbulkan Kerugian Para Pihak", Lentera Hukum, Volume 5, hlm. 331.
} 
sebagaimana yang diatur dalam UUJN. Sanksi pada hakikatnya merupakan instrumen yuridis yang biasanya diberikan apabila kewajiban-kewajiban atau larangan-larangan yang ada dalam ketentuan hukum telah dilanggar.

Sanksi kepada notaris merupakan penyadaran bahwa notaris dalam melakukan tugas jabatannya telah melanggar ketentuan-ketentuan mengenai pelaksanaan tugas jabatan notaris sebagaimana tercantum dalam UUJN, dan untuk mengembalikan tindakan notaris dalam melaksanakan tugas jabatannya untuk tertib sesuai dengan UUJN. Pasal 84 dan Pasal 85 UUJN mengatur mengenai 2 (dua) macam sanksi terhadap notaris, yaitu sanksi perdata dan sanksi administratif.

Notaris ditarik sebagai Tergugat bila dirasa telah melakukan suatu kesalahan yang seharusnya tidak dilakukan sebagai pejabat negara dan melanggar kode etik notaris serta UUJN. Pasal 1365 KUHPerdata mengatur mengenai perbuatan melawan hukum, yaitu: “tiap perbuatan melanggar hukum, yang membawa kerugian kepada seorang lain, mewajibkan orang yang karena salahnya menerbitkan kerugian itu, mengganti kerugian tersebut". Hubungan sebab akibat atau hubungan kausal antara perbuatan pelaku dengan akibat yang ditimbulkannya menjadi syarat dalam perbuatan melawan hukum.

Pasal 84 UUJN menyebutkan bahwa pihak yang dirugikan dengan berubahnya kekuataan pembuktian akta notaris dapat menggugat notaris. Sanksi perdata berupa penggantian biaya, gati rugi, dan bunga dapat dijatuhkan kepada notaris apabila akta yang dibuatnya hanya mempunyai kekuataan pembuktian sebagai akta dibawah tangan atau menjadi batal demi hukum. Pihak yang karena perbuatannya menimbulkan kerugian kepada pihak pihak harus bertanggung jawab dan mengganti kerugian yang timbul karena perbuatan tersebut, termasuk notaris.

Apabila notaris berkedudukan sebagai Turut Tergugat, maka sesungguhnya memiliki peran yang krusial terhadap isi putusan, dimana antara lain putusan hakim yang juga merupakan akta otentik juga akan mengikat turut tergugat untuk patuh terhadap putusan tersebut, sedangkan bila notaris berkedudukan sebagai saksi maka memiliki kewajiban untuk memberikan keterangan didepan hakim persidangan atas apa yang ia lihat, dengar, dan saksikan. 


\section{KESIMPULAN}

Notaris sebagai pejabat negara memiliki kewenangan membuat akta otentik berdasarkan perintah peraturan perundang-undangan dan keinginan para pihak. Oleh karena sesungguhnya apa yang dituangkan oleh notaris dalam akta berdasatkan keinginan para pihak sebagai penghadap. Dalam hal timbul permasalahan dikemudian hari atas terbitnya akta otentik yang dibuat oleh notaris, tidak serta merta notaris dapat ditarik sebagai pihak yang bersalah yang mengakibatkan persengketan tetapi harus dilihat sejauhmana pelanggaran yang telah dilakukan oleh notaris, apakah ada kesalahan/tidak, pelanggaran terhadap kode etik dan atau UUJN. Dalam penyelesaian sengketa di pengadilan dalam sengketa perdata, notaris dapat saja berkedudukan sebagai pihak antara lain Tergugat jika dirasa telah melakukan perbuatan melawan hukum sehingga merugikan pihak lain, sebagai Turut Tergugat, atau saksi.

Tanggung jawab notaris/PPAT tergantung dari kedudukannya dalam penyelesaian sengketa, namun pada intinya mempertanggungjawabkan perbuatannya baik secara perdata dengan dasar perbuatan melawan hukum, pidana, maupun administratif.

\section{SARAN}

Notaris dalam menjalankan tugas dan kewenangannya sebagai pejabat umum pembuat akta otentik harus cermat, teliti, dan saksama agar akta yang dibuatnya tidak menimbulkan kerugian baik materil maupun moriil di kemudian hari.

Pihak penggugat sebaiknya mampu mengkualifikasikan kedudukan notaris dalam mengajukan gugatan ke pengadilan sehingga dapat mendudukkan notaris sebagai pihak yang tepat.

\section{DAFTAR PUSTAKA}

\section{Buku}

A Kohar. (1983). Notaris Dalam Praktik Hukum, Bandung: Alumni.

Anita Afriana, et.all (2020). Hukum Perlindungan Konsumen: Dimensi Penyelesaian Sengketa, Bandung: Global Sinergi.

Bahtiar Effendi dkk.(1991). Surat Gugatan dan Hukum Pembuktian Dalam Perkara Perdata. Bandung: Citra Aditya Bakti. 
Bambang Waluyo. (1992). Sistem Pembuktian dalam Peradilan Indonesia, Jakarta: Sinar Grafika.

Habib Adjie. (2009). Hukum Notaris Indonesia (Tafsir Tematik Terhadap Undang-Undang Nomor 30 Tahun 2004 Tentang Jabatan Notaris), Bandung: PT. Refika Aditama.

Komar Andasasminta. (1983). Notaris Selayang Pandang, Bandung: Alumni.

Subekti, (1991). Hukum Pembuktian.Jakarta: Pradnya Paramit.

Sudikno Mertokusumo. (2009). Hukum Acara Perdata di Indonesia Edisi Ke Delapan, Yogyakarta: Liberty.

\section{Jurnal}

Dewi Tuti Muryati dan B. Dini Heryanti, (2011). “Pengaturan dan Mekanisme Penyelesaian Sengketa Non Litigasi di Bidang Perdagangan", Jurnal Dinamika Sosbud, Vol. 13, No. 1 .

Efa Laela Fakhriah, (2015). “Alat Bukti dalam Penyelesaian Perkara Perdata di Pengadilan menuju Pembaharuan Hukum Acara Perdata", Jurnal Hukum Acara Perdata, Vol 1 No. 2.

Shafira Meidina Rafaldini; Anita Afriana, Pupung Faisal, (2020). “Surat Keterangan Waris yang Memuat Keterangan tidak Benar Dikaitkan dengan Kekuatan Pembuktiannya sebagai Akta Otentik', Jurnal Hukum Acara Perdata, Vol 6 No. 1.

\section{Peraturan Perundang-Undangan}

Kitab Undang-Undang Hukum Perdata.

Undang-Undang Nomor 2 Tahun 2014 Tentang Perubahan Atas Undang-Undang No. 30 Tahun 2004 Tentang Jabatan Notaris.

\section{Sumber Lain}

Suyitno LS, 2007, Pejabat Pembuat Akta Tanah, (Makalah disampaikan pada Kongres IV Ikatan Pejabat Pembuat Akta Tanah (IPPAT) dan Up Grading Refreshing Course, Surabaya, 30-31 Agustus-1 September 2007). 